\title{
Cats as a reservoir of Bartonella henselae for dogs
}

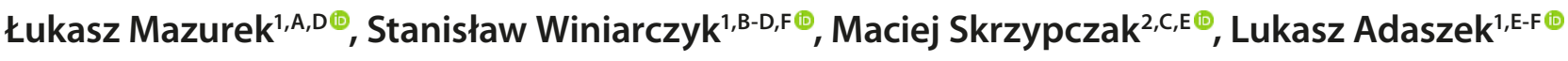 \\ ${ }^{1}$ Faculty of Veterinary Medicine, University of Life Sciences, Lublin, Poland \\ 2 Second Department of Gynecology, Medical University, Lublin, Poland \\ A - Research concept and design, B - Collection and/or assembly of data, C - Data analysis and interpretation, \\ $D$ - Writing the article, E - Critical revision of the article, F- Final approval of article
}

Mazurek $Ł$, Winiarczyk S, Adaszek S, Skrzypczak M. Cats as a reservoir of Bartonella henselae for dogs. Ann Agric Environ Med. 2019; 26(4): 669-671. doi: 10.26444/aaem/105396

\begin{abstract}
Bartonellosis is a disease affecting a variety of animals. Many Bartonella infections are zoonotic, including cat scratch disease. Within the genus Bartonella are 45 species, of which more than 10 can infect cats and dogs. Companion animals serve as reservoirs for several zoonotic species of Bartonella, and may also serve as sentinels for zoonotic Bartonella species harbored by wildlife. The aim of this study was to determine the frequency of the occurrence of Bartonella spp. DNA in dogs from households where cats with clinical bartonellosis were kept. The presence of DNA with 99-100\% compliance of the nucleotide sequence with the sequence of the Bartonella DNA isolated from cats was demonstrated in the body of $10 \%$ of tested dogs. The results indicate that cats serve as a Bartonella reservoir for dogs, and the dogs can play the same role with regard to humans.
\end{abstract}

Key words

Bartonella spp., dogs, PCR, vector-borne disease

\section{INTRODUCTION}

Bartonellosis is a disease caused by Bartonella spp., which belong to the order Rickettsiales. Within the genus Bartonella there are 45 species, of which more than 10 can infect cats and dogs. Bartonella are pleomorphic, Gram-negative, intracellular bacilli with a size of $0.3-0.6 \times 0.3-1.0 \mu \mathrm{m}$ [1]. The disease is a zoonosis, $B$. henselae, which in humans causes a cat-scratch disease. Although cats are considered to be the primary reservoir host for B. henselae, DNA of this bacterial species has been found in dogs, cows, horses, feral swine, marine mammals and sea turtles [1]. Dogs infected with $B$. henselae display a wide clinical spectrum similar to that observed in humans $[2,3]$.

Data concerning bartonellosis in dogs in Poland are scarce. The presence of the DNA of these Rickettsiales has been demonstrated in the blood of $1 \%$ of dogs with suspected borreliosis [4]. In turn, in one study, Podsiadły et al. [5] demonstrated the presence of low titers of antibodies against Bartonella in the blood of $49 \%$ dogs in Poland.

Cat fleas (Ctenocephalides felis) are considered to be the primary vector for transmission to reservoir and potentially non-reservoir hosts, such as dogs and humans; however, $B$. henselae DNA has also been amplified from Ixodes ticks [6] and woodlouse hunter spiders [5, 7]. It is not entirely clear what serves as a Bartonella reservoir for dogs. It is assumed that in households where dogs are kept together with cats, the latter may serve as such reservoirs [8].

The aim of the study was to determine the frequency of occurrence of Bartonella spp. DNA in dogs from households where cats with clinical bartonellosis were kept.

Address for correspondence: prof. Łukasz Adaszek, Department of Epizootiology Faculty of Veterinary Medicine, University of Life Sciences, Lublin, Poland E-mail: ukaszk0@wp.pl

Received: 16.11.2018; Accepted: 15.02.2019; first published: 18.03.2019

\section{MATERIALS AND METHOD}

The study involved 40 dogs: 32 males and 8 females (Tab. 1) from households located in the east of Poland, where cats with clinical bartonellosis caused by $B$. henselae were identified. None of the dogs showed any disease symptoms: body temperature, heart rate and respiratory rate were within the reference ranges, palpable lymph nodes were not enlarged, none of the dogs showed signs of systemic illness (Tab. 1). All 40 dogs had contact with sick cats. Twenty-six dogs were kept inside houses, the other 14 in dog pens. All dogs were vaccined against parvovirosis, distemper, adenovirosis, parainfluenza and rabies, and also received prophylaxis against ectoparasites (depending on the form of the used product: tablets, spoton, collar, every 1-3 months). During the anamnesis, it was established that the owners did not record the presence of ticks or fleas on the dogs' bodies. Also during the clinical examination of the animals (in most cases the wet paper test was performed) no ectoparasites were observed on the body surface of the animals. Blood samples were taken from all dogs during a visit in the clinic, and tested for bartonellosis using molecular methods. Blood examination was part of regular control clinical examination which is performed on patients of the Clinic of Infectious Diseases in Lublin at least once a year. All owners agreed to the collection and examination of blood.

DNA extractions for molecular tests were performed using the DNA Blood kit (A\&A Biotechnology Gdańsk, Poland). The extracted DNA was subjected to PCR, performed with the primers targeting fragments of the citrate synthase gene: one generic forward primer (BART- LC-GEN-F: 5' ATGGGTTTTGGTCATCGAGT - 3'); one specie-specific reverse $B$. henselae, primer (BART-LC-HEN-R: 5'-AA ATCGACATTAGGGTAAAGTTTTT - 3'); and one species specific reverse $B$. clarridgeiae primer (BART-LC-CLA-R: 5'- CAAGAAGTGGATCATCTTGG - 3'), according to the method described by Staggemeter et al. [9], with small 
Table 1. Description of the dogs using in the study

\begin{tabular}{|c|c|c|c|c|c|c|c|c|c|}
\hline No & Gender & Age & Breed & Body weight (kg) & Way of keeping & Body temp. $\left(^{\circ}\right)$ & $\mathrm{HR}$ (min) & $\mathrm{RR}(\min )$ & Prophylaxis against ectoparasites \\
\hline 1. & Female & 2 years & German Shepherd & 30 & Pen & 37,8 & 83 & 12 & Collar \\
\hline 2. & Female & 4 years & Mix & 7 & House & 38,0 & 106 & 26 & Spot-on \\
\hline 3. & Female & 1,5 year & Boxer & 28 & House & 37,7 & 96 & 21 & Spot-on \\
\hline 4. & Female & 5 years & Alaskan malamulte & 35 & Hose & & 88 & 18 & Tablets \\
\hline 5. & Female & 2 years & Mix & 14 & Pen & 38,2 & 110 & 30 & Tablets \\
\hline 7. & Female & 6 months & Irish setter & 25 & House & 38,0 & 88 & 22 & Tablets \\
\hline 8. & Female & 3 years & Mix & 6 & Pen & 38,9 & 112 & 29 & Spot-on \\
\hline 9. & Male & 5 years & Mix & 10 & Pen & 38,1 & 99 & 21 & Spot-on \\
\hline 10. & Male & 1,5 year & Dachshund & 9 & House & 37,7 & 92 & 26 & Tablets \\
\hline 11. & Male & 6 years & Mix & 17 & House & 38,2 & 85 & 20 & Spot-on \\
\hline 13. & Male & 10 years & Schnauzer & 15 & House & 37,6 & 80 & 20 & Tablets \\
\hline 14. & Male & 1,5 year & Mix & 18 & House & 38,4 & 91 & 22 & Spot-on \\
\hline 15. & Male & 7 years & Mix & 10 & Hose & 38,9 & 111 & 28 & Spot-on \\
\hline 16. & Male & 1 year & Dog & 46 & House & 37,9 & 77 & 16 & Collar \\
\hline 17. & Male & 4 year & Bernese mountain dog & 52 & Pen & 37,6 & 75 & 20 & Collar \\
\hline 18. & Male & 5 year & Mix & 10 & House & 38,0 & 115 & 30 & Spot-on \\
\hline 19. & Male & 11 years & Irish setter & 33 & House & 38,1 & 78 & 11 & Tablets \\
\hline 20. & Male & 5 years & Mix & 16 & Hose & 38,6 & 118 & 32 & Spot-on \\
\hline 21. & Male & 2 years & German Shepherd & 32 & House & 38,0 & 86 & 21 & Tablets \\
\hline 22. & Male & 3 years & Doberman & 37 & House & 37,8 & 97 & 27 & Tablets \\
\hline 23. & Male & 10 years & Mix & 19 & Pen & 38,2 & 102 & 28 & Spot-on \\
\hline 24. & Male & 8 years & Mix & 15 & Pen & 38,7 & 113 & 25 & Collar \\
\hline 26. & Male & 4 years & Cane corso & 44 & House & 38,0 & 72 & 15 & Tablets \\
\hline 27. & Male & 7 years & Mix & 9 & House & 38,8 & 93 & 16 & Spot-on \\
\hline 28. & Male & 8 years & German Shepherd & 37 & Pen & 37,9 & 82 & 19 & Tablets \\
\hline 29. & Male & 2 years & Mix & 12 & Pen & 38,1 & 90 & 13 & Spot-on \\
\hline 30. & Male & 3 years & Jack Russel Terrier & 10 & House & 37,9 & 88 & 22 & Spot-on \\
\hline 31. & Male & 6 years & Mix & 8 & Pen & 37,6 & 107 & 26 & Spot-on \\
\hline 32. & Male & 2 years & Cocker spaniel & 14 & House & 37,7 & 95 & 23 & Tablets \\
\hline 33. & Male & 4 years & Mix & 23 & House & 38,1 & 82 & 20 & Spot-on \\
\hline 34. & Male & 10 years & German Shepherd & 35 & Hose & 37,8 & 80 & 20 & Collar \\
\hline 35. & Male & 6 years & Jack Russel Terrier & 11 & House & 38,8 & 103 & 26 & Tablets \\
\hline 36. & Male & 2 years & Mix & 8 & House & 37,9 & 109 & 24 & Spot-on \\
\hline 37. & Male & 8 years & Mix & 17 & Hose & 38,3 & 100 & 25 & Spot-on \\
\hline 38. & Male & 5 years & Mix & 20 & Pen & 38,6 & 88 & 27 & Spot-on \\
\hline 39. & Male & 7 years & German Shepherd & 41 & Pen & 38,1 & 81 & 19 & Spot-on \\
\hline 40. & Male & 2 years & Mix & 11 & Pen & 38,5 & 92 & 22 & Tablets \\
\hline
\end{tabular}

modifications: an initial denaturation of $2 \mathrm{~min}$ at $95^{\circ} \mathrm{C}$, followed by 37 cycles consisting of denaturation at $96^{\circ} \mathrm{C}$ for $60 \mathrm{~s}$, annealing at $55^{\circ} \mathrm{C}$ for $60 \mathrm{~s}$ and elongation at $72^{\circ} \mathrm{C}$ for 90 s. Reaction mixture $(50 \mu \mathrm{L})$ contained $100 \mu \mathrm{M}$ of each $\mathrm{dNTP}, 1.6 \mathrm{mM}$ of $\mathrm{MgCl} 2,0.25 \mu \mathrm{M}$ of each primer, $2.5 \mathrm{U}$ of Taq DNA polymerase, and $5 \mu \mathrm{L}$ of DNA template. A negative control, consisting of distilled water, and positive control, consisting of extracted DNA from a blood sample known to contain $B$. henselae (obtained from Institute of Parasitology, Academy of Science, Kosice, Slovakia), were used in each PCR run.
The size of each PCR product was analysed by electrophoresis in a $1.5 \%$ agarose gel stained with ethidium bromide. The PCR products were purified using QIAquick spin columns (Qiagen) and eluted in $50 \mu \mathrm{l}$ of Tris $10 \mathrm{mM}, \mathrm{pH}$ 7.6. The DNA sequence was determined on both strands using the same primers employed for PCR at a DNA sequencing core facility (Institute of Biochemistry and Biophysics, Polish Academy of Sciences, Warsaw, Poland). The DNA sequences were assembled and edited using SeqMan (DNAstar, Lasergene, Madison, USA), and ClustalV alignments. 


\section{RESULTS AND DISCUSSION}

The presence of $B$. henselae DNA was detected in the blood of four out of 40 tested individuals (10\%). The size of the amplified citrate synthase gene fragment was $250 \mathrm{bp}$. Sequencing the PCR product obtained from the dogs and comparing its nucleotide sequence with the sequence of the gene fragment obtained from the cats from the same hosehold, as well as with the sequence deposited in GenBank under Accession No. L38987.1, showed a high level of homology: 99-100\%. The dogs infected with bacteria came from urban (two individuals) and from rural areas (two individuals).

These results indicate that the problem of bartonellosis in dogs in Poland may be more significant than is assumed. In own studies the presence of the DNA of these pathogens were detected in $10 \%$ of the tested animals which manifested no clinical symptoms of the disease. However, the results concerned a small group of dogs, which additionally were more likely to become infected due to their contact with cats which were infected with Bartonella.

In 2006-2008, Welc-Falęciak et al. [10] examined 82 sled dogs for tick-borne diseases but did not detect the Bartonella spp DNA in the blood of any of the tested animals. Rymaszewska and Adamska [4] found such DNA in 1\% of dogs with suspected Lyme disease, but none in 100 healthy subjects.

A comparison between those results and the results of the presented study leads to the coonclusion that the problem of dog bartonellosis in Poland may be underestimated. In neighbouring countries, a molecular monitoring of dog bartonellosis has been conducted only in the Czech Republic, where Konvalinova et al. [11] demonstrated the presence of the DNA of these pathogens only in $0.7 \%$ of $286 \mathrm{dogs}$, both healthy and with various health problems. Although the mode of infection was not determined, the bacteria could have been transmitted by scratching during a fight between a dog and a cat from the same household, or by flea transmission between these animals, as identical citrate synthase gene fragments of $B$. henselae were amplified and sequenced from the dog and cat blood.

Flea-infested cats may be a source of infection for domestic dogs. Flea transmission from $B$. henselae bacteremic cats to specific pathogen-free dogs has been documented experimentally [8]. On the other hand, dogs might serve as a source for human Bartonella spp. infections. In China, the seropositivity rate among dog bite victims was significantly higher than the seroprevalence among blood donors [12]. Despite an increasing number of canine bartonellosis reports being published, dogs are still not considered to be a major reservoir for $B$. henselae.
B. henselae detected in the blood of four dogs in the current study is a serious zoonotic agent, and the obtained results show the necessity of considering dogs as a potential source of human infection. On the other hand, it is necessary to point to the fact that cats are also a potential source of direct (by scratching or by bite) or indirect (by fleas) infection for dogs.

The prevention of bartonellosis generally lies in the protection of animals against flea and tick infestation. It is therefore advisable to treat animals with anti-parasitics on a regular basis, either in the form of spray, spot on, oral drugs or collars. These measures do not give full protection against infection, but they reduce significantly the possibility of its development.

\section{REFERENCES}

1. Breitschwerdt EB, Maggi RG, Chomel BB, Lappin MR. Bartonellosis: an emerging infectious disease of zoonotic importance to animals and human beings. J Vet Emerg Crit Care 2010; 20(1): 8-30.

2. Breitschwerdt EB, Linder KL, Day MJ, Maggi RG, Chomel BB, Kempf VA. Koch's postulates and the pathogenesis of comparative infectious disease causation associated with Bartonella species. J Comp Pathol. 2013; 148 (2-3):115-125.

3. Chomel BB, Kasten RW. Bartonellosis, an increasingly recognized zoonosis. J Appl Microbiol. 2010; 109(3): 743-750.

4. Rymaszewska A, Adamska M. Molecular evidence of vector-borne pathogens coinfecting dogs from Poland. Acta Vet Hung. 2011; 59(2): 215-223.

5. Podsiadly E, Chmielewski T, Marczak R, Sochon E, TylewskaWierzbanowska S. Bartonella henselae in the human environment in Poland. Scand J Infect Dis. 2007; 39(11-12): 956-962.

6. Dietrich F, Schmidgen T, Maggi RG, Richter D, Matuschka FR, Vonthein R, Breitschwerdt EB, Kempf VA. Prevalence of Bartonella henselae and Borrelia burgdorferi sensu lato DNA in Ixodes ricinus ticks in Europe. Appl Environ Microbiol. 2010; 76(5): 1395-1398.

7. Mascarelli PE, Maggi RG, Hopkins S, Mozayeni BR, Trull CL, Bradley JM, Hegarty BC, Breitschwerdt EB. Bartonella henselae infection in a family experiencing neurological and neurocognitive abnormalities after woodlouse hunter spider bites. Parasites Vectors 2013; 6: 98.

8. Drut A, Bublot I, Breitschwerdt EB, Chabanne L, Vayssier-Taussat M, Cadoré JL. Comparative microbiological features of Bartonella henselae infection in a dog with fever of unknown origin and granulomatous lymphadenitis. Med Microbiol Immunol. 2014; 203(2): 85-91.

9. Staggemeier R, Pilger DA, Spilki FR, Cantarelli VV. Multiplex SYBR ${ }^{\star}$ green-real time PCR (qPCR) assay for the detection and differentiation of Bartonella henselae and Bartonella clarridgeiae in cats. Rev Inst Med Trop Sao Paulo 2014; 56(2): 93-95.

10. Welc-Faleciak R, Rodo A, Siński E, Bajer A. Babesia canis and other tick-borne infections in dogs in Central Poland. Vet Parasitol. 2009; 166(3-4): 191-198.

11. Konvalinová J, Svobodová V, Molinková D, Svoboda M. PCR detection of Bartonella spp. in the dog. Acta Vet Brno 2014; 83: 79-82.

12. Sun J, Fu G, Lin J, Song X, Lu L, Liu Q. Seroprevalence of Bartonella in Eastern China and analysis of risk factors. BMC InfectDis. 2010; 10: 121.

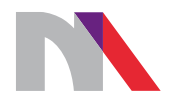

Ministry of Science and Higher Education

Republic of Poland

Generation of the DOI (Digital Object Identifier) - task financed under the agreement No. 618/P-DUN/2019 by the Minister of Science and Higher Education 